\title{
PARENTAL SPEECH AS LINGUISTIC INPUT FOR CHILDREN
}

\author{
Riana Agustin Tindjabate \\ Email: ra tindjabate@yahoo.co.id \\ Program Studi Pendidikan Bahasa Inggris Universitas Kristen Tentena
}

\begin{abstract}
Abstrak
Pemerolehan bahasa anak dipengaruhi oleh banyak faktor termasuk faktor keluarga. Teori Chomsky tentang pemerolehan bahasa anak mengatakan bahwa seorang anak terlahir dengan kemampuan bahasa yang sudah terprogram dalam otaknya. Sistem tersebut akan bekerja secara maksimal sesuai perkembangan usia anak sehingga anak tidak memerlukan orang lain untuk membantu perkembangan bahasanya. Hal ini tidak sepenuhnya diterima oleh ahli bahasa yang lain karena ada yang menganggap bahwa faktor orang tua sangat berperan dalam perkembangan bahasa anak. Kajian ini fokus pada input orang tua yang diberikan kepada anak secara linguistic melalui interaksi dan metode membaca cerita.

Kata kunci: ucapan orangtua, input secara linguistic, anak-anak
\end{abstract}

\begin{abstract}
Child language acquisition is influenced by many factors including family factors. Chomsky theories on child language acquisition say that a child born with language skills that are hardwired in the brain. The system will work optimally with the development age of the child so that the child does not need others to help his language development. It is not fully accepted by other linguists because some people think that the parents are very instrumental factor in the development of children's language. This study focuses on the input of parents were given to children in linguistic through interaction and methods of reading the story. Keywords: parental speech, linguistic input, children
\end{abstract}

\section{INTRODUCTION}

First language acquisition of children has been an interesting and challenging research topic for many years even to the present days. Many linguists conducted researches on the topic in different context and found out particular approaches of language acquisition such as behaviorism, through theories of first language acquisition such as behaviorism and functional approaches, the basic concepts of children's first language acquisition.
These theories then lead us to the comprehension that first language acquisition has many aspects to be explored such as the neurological, psychomotor, cognitive, affective and linguistic aspects. Children, in their first language acquisition process, are very influenced by those aspects which enriching their everyday speech.

Let us see to Noam Chomsky's theory. Chomsky believes that to acquire first language, children do not need 
another person because children are born with innate knowledge of how to use language. It has been programmed in their brain. They have competence to utter words and will produce more complex sentences grammatically together with the development of their brain and articulators' position (Brown, 1980:19). Thus, Chomsky does not deeply consider the significant space between children and their environment (home, school, neighborhood, friends etc) whereas Brown (1980:32) cited it is hard to deny and ignore the role of input in the child's acquisition of language because it is very crucial. Of course those statements above make us little bit confused. Neurologically, we can accept Chomsky's theory which states that on the day he/she is born, a child has language acquisition device (LAD). However, it is hard to ignore the linguistic input of parents as experienced by children in their linguistic development.

There is a child named Ari (three years old). He lives with his parents. $\mathrm{He}$ has difficulties to pronounce words separately. One day, I asked a question to him, "Ari makan apa?" He answered, "matayamgomigo". I observed his meal and I saw fried chicken and fried noodle on his plate. Actually, he wanted to answer my question by saying "makan ayam goreng dan mi goreng”. This child Ari understood my question however he could not pronounce each words correctly probably due to the limitation of his linguistic skills by his age (Kapoh, 2010).

I assumed it was because of non optimal parental input in his linguistic skills. I have not heard his parents correcting his pronunciation, words or giving him example to ask or utter something. This is why I am interested to the Brown's statement which says that input has significant role in child's acquisition of language because parent is the first person who mostly interacts with the child on the day he is born.

\section{Review on Parental Input}

There are few linguistic terms used in this paper. To avoid some misleading comprehensions, I need to make review of the terms that the readers will have the same comprehension.

\section{Parental Speech as linguistic input for children}

Children spend much of their time at home. They hear the speech of their parents and older siblings every time. The speech is full of performance variables and not followed by the rules of grammar in general thus children gain chaotic sample of language, then their innate competence can support them to acquire ability to produce utterances and words as said by Brown (1980). Hladik and Edwards; Moerk in Brown (1980) found out that the 
parental speech as linguistic input to their children are chosen carefully, it is functional, simple to be understood but not chaotic. Based on the previous review, we discover that children might expose various linguistic input of parental speech due to their parents' life background.

\section{Interaction between children and parents}

The way children produce words is unable to be separated from their home environment. Children mostly communicate with people who live together with them. Generally, children can distinguish between mother's voice and the voices of other people at the age of one month as mentioned by Wisniewski (2007). This statement is supported by Plessis (2010) by saying that children begin to learn language on the day they are born. Therefore, it is the responsibility of their parents to make children accustomed with correct speech sounds. It is important for the children's linguistic capacity building. The responsibility must be done continuously with good assistance from the parents so that their children acquire optimal language skills.

\section{DISCUSSION}

Children have brain, cognition, organ of speech and emotion as the elements to support them learning language. To use the elements optimally in learning first language, children need external factors such as the input of parents, teacher, social culture, care taker and so on. Why do I say this? A child has limited capacities of linguistic comprehension and production. Their organs of speech are developing as well as their brain. The ability of children to use language also depends on active stimulus and response of other people surrounding them even though innate knowledge of using language has been there when they are still in fetus.

\section{The role of mother}

We can imagine a child growing up without interactive communication with his parents whereas his capacity development totally depends on his parents' role and support during his golden period. Plessis (2010) deeply considers the awareness of mothers to talk continually to their children when feeding, bathing, and dressing them lest their children are going to be late talker.

I have a daughter named Hena. At the age of one month, she could distinguish my voice sounds, her father's even her grandfathers'. She cried loudly if another person carried her but when I called her name then took her while singing a song, she stopped crying and became quiet. Mostly, at the age of one month up children are able to distinguish 
between their mother's voice such as joyful, angry or shooting tones (Wisniewski, 2007:1-2).

When she was still a little baby, I frequently mentioned her name to start talking with her and this has been influencing her language skills. The first utterance of my daughter was produced by her when she was eight months old. That was mama. Then, at 11 months old she produced "nena muna". She produced that utterance when I or someone took her toys. Her ability to perform what was in her mind by producing "nena muna' was also influenced by my speech because I asked frequently a question to her "ini hena punya?" while holding a toy. From my own experience above, we can see that my daughter gave active response on my stimulus and positive reinforcement. As said by Mason (2010) children move from a passive position to an active position as their reaction on their parents' utterances. Children make passive vocabulary when they are listening to another people speech then they make active vocabulary when uttering something.

\section{Parental input in children's development of conversational rules}

My husband is a Javanese. When I

ask a question to him and the answer is "no", he will say "nggak". One day I brought some cakes from my office and I found Hena was sitting in the living room while playing her dolls. She was three years old at the time. I wanted to know whether she wants to eat the cake or not so I asked her "Hena mau kue?", she answered, "nggak". I felt a little bit funny at that time when she preferred to use "nggak" rather than "tidak" as I always use to say "no". Hena sometimes used "tidak" however "nggak" is frequently used by her to respond such question. Her ability to use "nggak" as the answer on my interrogative sentence was influenced by her father's speech which occurred frequently at home. She has two options of word in her mind which has the same meaning "tidak" and "nggak". That is a simple example of how a child responding adult initiating and how the parental input gives contribution to their ability in speaking. In this phase, a child is trying to develop his/her grammatical ability (Hartati, 2014).

Children are active participants in acquiring language. They are creative in developing their first language acquisition. They can distinguish differences intonation, personal desires and social interactions. They do not only imitate or repeat the language that they hear around them but they deduce it then they use the language to create a phrase or sentence which they never hear before. However, the role of parent is still very important in 
the development of their conversational rules (Mason, 2010). Parents should optimally build linguistic foundation of their children if they want their children have good refinement, in the present and in the future. So that, they will get attention from the hearer or audience when they are speaking or talking. Many ways are able to be applied in order to develop children's linguistic skills. Do not simply talking and talking to them but enriching their vocabulary with new words, phrases and sentences, giving good example in pronouncing words, correcting their intonation, repeating patiently the phonetic sounds and words which are very difficult to them to pronounce. These efforts will help children in using language wherever they are. On the day a child is delivered, a child learns to get attention from people around him by crying loudly as cited by Brown (1980) that the first and the essential rule of conversation is attention getting. Since the day, children have to be taught the rules of conversation in order to get attention. Interruption is a form of attention getting. Generally, children are unable to interrupt politely when they are making conversation especially at school age. Parents should teach their children the polite way to interrupt conversation.

\section{Learning first language through reading} story
Reading story over and over to a child will be worthwhile to his vocabulary besides talking to him continually. Maybe at the age of two years he cannot write and read words, phrases or sentences but the vocabulary in the story which read by his parents becoming part of his everyday speech (Plessis 2010). This effort can develop a child's language acquisition; enriching vocabulary and preventing a child being a late talker even his refinement becoming better than of his age group.

Reading story is one of language learning method. Parents should be creative in teaching and learning first language to their children. The ability of children to speak fluently and use vocabulary actively will support them to enrich their knowledge and get active interaction with people around them.

\section{CONCLUSION}

Parents play significant role in developing the child's first language acquisition. We can see that parents play role as a creative facilitator, motivator, model even one of linguistic source to their children. I am not saying that the only significant input in the child's first language acquisition is the role of parental input but through the discussion above, it 
shows that the development of child's linguistic skill is inseparable from parental input. We can imagine how if parents forget or ignore their roles as facilitator, motivator, model and source of their children in learning language. Children will learn by themselves, they do not know even not care whether the language using by them is polite or proper in certain or any situation. Children, who lost control or role from their parents in using language, are difficult to get attention from another people when they start to speak. It can be happened at home, schools, or anywhere they go.

Moreover, the language acquisition device which has been there since a child born, will stay as passive competence for aver if his parents believe that the first language acquisition of a child developing automatically without teaching and learning process. Nothing in the world, that human being knows or can do without the process of learning (Plessis, 2010). Finally, by giving optimal input to children in their language learning and acquisition process, we are educating them being a civilized person.

\section{References}

Brown, H.D. 1980. Principles of Language Learning and Teaching. New Jersey:

Prentice Hall Regents

Brown, H.D. 1980.Principles of Language Learning and Teaching, $2^{\text {nd }}$. New Jersey: Prentice Hall Regents
Hartati, Tatat. Pemerolehan dan Perkembangan Bahasa Anak. https://www.google.co.id/webhp?sourceid =chromeinstant\&ion $=1 \&$ espv $=2 \&$ ie $=$ UTF8\#q=pemerolehan\%20bahasa\%20anak (downloaded on $13^{\text {th }}$ of May 2014)

Kapoh, Ruty J. 2010. Beberapa Faktor yang Berpengaruh terhadap Perolehan Bahasa. Interlingua, Vol 4, April 2010. https://www.google.co.id/webhp?sourceid =chrome$\underline{\text { instant } \& \text { ion }}=1 \&$ espv $=2 \&$ ie $=U T F-$ $\underline{8 \# q=\text { faktor+yang+mempengaruhi+pemero }}$ lehan+bahasa+anak

Mason, Timothy. 2002. Learning Language. www.timothyjpmason.com (downloaded on $13^{\text {th }}$ of May 2014)

Plessis, Du Susan. 2010. Language Acquisition in Children. www.learninginfo.org (downloaded on $12^{\text {th }}$ of May 2014

Wisniewski, Kamil. 2007. First Language Acquisition. www.tlumaczeniaangielski.org (downloaded on $12^{\text {th }}$ of May 2014 
Jurnal Akademia, Volume 1, Nomor 2, Oktober-Desember 2014 